\title{
PENGARUH CHALLENGE BASED LEARNING DENGAN METODE EKSPERIMEN DAN PROYEK DITINJAU DARI SIKAP ILMIAH DAN KEINGINTAHUAN TERHADAP PRESTASI BELAJAR SISWA
}

\author{
Sodikin \\ Program Studi Pendidikan Fisika, FTK IAIN Raden Intan Lampung
}

\begin{abstract}
Abstrak: Tujuan penelitian adalah untuk mengetahui pengaruh model challenge based learning $(C B L)$ dengan metode eksperimen dan proyek, sikap ilmiah, keingintahuan belajar, dan interaksinya terhadap prestasi belajar ranah kognitif, afektif, dan psikomotorik siswa. Penelitian ini merupakan penelitian eksperimen semu dengan desain faktorial 2x2x2. Populasi penelitian ini adalah seluruh siswa kelas X MAN 1 Bandar Lampung semester II Tahun Pelajaran 2013/2014. Sampel terdiri dari dua kelas yaitu kelas X2 dan X3 yang diperoleh menggunakan teknik cluster random sampling. Kelas X2 diberi model $C B L$ dengan metode eksperimen dan kelas X3 diberi model $C B L$ dengan metode proyek. Uji hipotesis menggunakan Anava. Berdasarkan hasil analisis disimpulkan: 1) ada pengaruh model $C B L$ dengan metode eksperimen dan proyek terhadap prestasi belajar kognitif sedangkan afektif dan psikomotorik tidak ada pengaruh; 2) ada pengaruh keingintahuan belajar terhadap prestasi belajar kognitif dan afektif sedangkan prestasi belajar psikomotorik tidak ada; 3) ada pengaruh sikap ilmiah terhadap prestasi belajar kognitif siswa, sedangkan pada afektif dan psikomotorik tidak ada; 4) tidak ada interaksi antara pengaruh model $C B L$ dengan metode eksperimen dan metode proyek dengan keingintahuan belajar terhadap prestasi belajar kognitif, afektif, dan psikomotorik siswa; 5) tidak ada interaksi antara pengaruh model $C B L$ dengan metode eksperimen dan metode proyek dengan sikap ilmiah terhadap prestasi belajar kognitif, afektif, dan psikomotorik siswa; 6) tidak ada interaksi antara pengaruh keingintahuan belajar dengan sikap ilmiah terhadap prestasi belajar kognitif, afektif, dan psikomotorik siswa; 7) tidak ada interaksi antara pengaruh model $C B L$ dengan metode eksperimen dan metode proyek, keingintahuan belajar, dengan sikap ilmiah terhadap prestasi belajar kognitif, afektif, dan psikomotorik siswa.
\end{abstract}

Kata Kunci: $C B L$, keingintahuan, pembelajaran eksperimen, sikap ilmiah

\section{PENDAHULUAN}

Proses pembelajaran sains di Indonesia sebagian besar masih berpusat pada guru (teacher centered). Pada saat pembelajaran, guru masih mendominasi proses pembelajaran. Hal tersebut menunjukkan bahwa dalam proses pembelajaran hanya terbatas pada transfer ilmu pengetahuan, sehingga siswa kurang dilibatkan dalam proses pembelajaran. Pembelajaran di kelas belum sejalan dengan filosofi pengetahuan itu sendiri. Pembelajaran masih berlangsung secara konvensional melalui ceramah tanpa memberi kesempatan yang lebih bagi siswa, baik untuk meningkatkan keterampilan berpikir kreatif dan keingintahuan siswa, sehingga pembelajaran tersebut menyebabkan rendahnya minat belajar siswa. Materi pembelajaran hanya disampaikan sebagai informasi, bukan sebuah konsep yang layak untuk dibangun atau ditelusuri secara ilmiah.

Rendahnya minat siswa dalam proses pembelajaran berdampak pada rendahnya hasil belajar siswa, khususnya pelajaran fisika. Prestasi belajar siswa untuk pelajaran fisika materi listrik dinamis relatif masih di bawah Kriteria Ketuntasan Minimal (KKM), seperti halnya yang terjadi di MAN 1 Bandar lampung.

MAN 1 Bandar lampung merupakan sekolah yang berasaskan agama Islam dan umum di Bandar lampung. Berdasarkan hasil wawancara pada 22 Desember 2013, dengan salah satu guru fisika Kelas X, hasil belajar fisika siswa belum memuaskan di MAN 1 Bandar lampung kemungkinan disebabkan oleh: siswa kurang diikutsertakan dalam partisipasi proses belajar-mengajar, penggunaan media pembelajaran yang kurang optimal sehingga 
karakteristik materi fisika tidak dapat dipahami siswa dengan baik, dalam pembelajaran masih terpusat pada guru, siswa kurang dilibatkan secara aktif, sehingga prestasi belajar siswa belum optimal, guru belum memerhatikan pentingnya keingintahuan dan sikap ilmiah siswa sebagai salah satu penentu keberhasilan siswa dan salah satu materi pembelajaran yang masih sulit dipahami dan dikuasai siswa adalah materi pembelajaran listrik dinamis. Data hasil uji kompetensi dasar materi listrik dinamis pada tahun pelajaran 2012/2013 menyatakan bahwa masih banyak siswa yang belum memenuhi nilai KKM.

Pembelajaran yang diterapkan di banyak sekolah seperti beberapa temuan Depdiknas lebih memprioritaskan pada kelulusan siswa dalam UN. Pembelajaran tersebut tentunya tidak lagi memperhatikan keutuhan dan hakikat materi pelajaran. Pembelajaran kurang melibatkan siswa untuk turut aktif dalam proses pembelajaran, sementara guru menjadi sumber belajar yang paling dominan. Pembelajaran yang demikian tentunya kurang melatih siswa untuk memunculkan keterampilan proses, sikap serta hanya menyentuh ranah kognitif. Proses pembelajaran ditekankan pada penyampaian informasi faktual yang tidak membutuhkan pemikiran yang mendalam pada proses penerimaan siswa.

Peraturan Menteri Pendidikan Nasional No. 45 Tahun 2010 tentang kriteria kelulusan peserta didik yang menyatakan bahwa kelulusan peserta didik dalam UN ditentukan berdasarkan Nilai Akhir (NA) yang diperoleh dari gabungan antara nilai Sekolah/Madrasah (S/M) dari mata pelajaran yang diujinasionalkan dan nilai UN dengan pembobotan $40 \%$ untuk nilai $\mathrm{S} / \mathrm{M}$ dari mata pelajaran yang diujinasionalkan dan $60 \%$ untuk nilai UN. Sedangkan, nilai S/M diperoleh dari gabungan antara nilai ujian $\mathrm{S} / \mathrm{M}$ dan nilai rata-rata rapor semester III, IV, dan V untuk Sekolah Menengah Atas/Madrasah Aliyah.

Peraturan di atas semestinya dapat mengubah paradigma para pendidik dan pelaku pendidikan dalam pembelajaran dan penilaian di kelas. Hal itu membuka kesempatan bagi guru untuk memberikan pembelajaran pada siswanya yang tidak terfokus pada ranah kognitif dan nilai ujian saja. Penilaian melalui ujian S/M dapat dilakukan tidak hanya melalui tes tertulis saja, tetapi juga tes praktik. Melalui tes praktik, guru dapat memasukkan keterampilan sebagai unsur penilaian. Demikian juga penilaian rapor yang dapat diambil selama pembelajaran, tentunya sangat memungkinkan bagi guru untuk mengambil penilaian dengan memandang proses selama pembelajaran, baik melalui keterampilan, maupun sikap siswa. Pada akhirnya, pola pembelajaran dapat bergeser pada pembelajaran yang mengajarkan aspek kognitif, afektif, dan psikomotorik siswa.

Kurikulum Tingkat Satuan Pendidikan (KTSP) mempertimbangkan pentingnya ilmu fisika dibelajarkan pada siswa SMA/MA, Pertama, selain memberi bekal ilmu kepada peserta didik, mata pelajaran fisika dimaksudkan sebagai wahana untuk menumbuhkan kemampuan berpikir yang berguna untuk memecahkan masalah dalam kehidupan sehari-hari. Kedua, mata pelajaran fisika perlu diajarkan untuk tujuan yang lebih khusus yaitu membekali peserta didik dengan pengetahuan, pemahaman, dan sejumlah kemampuan yang dipersyaratkan untuk memasuki jenjang pendidikan yang lebih tinggi serta mengembangkan ilmu dan teknologi.

Pembelajaran yang memperhatikan proses dan produk hendaknya selain bertujuan untuk meningkatkan pengetahuan siswa, juga memiliki sasaran agar dapat melatih kompetensi berpikir siswa dari keterampilan berpikir tingkat rendah hingga keterampilan berpikir tingkat tinggi seperti keterampilan berpikir kritis dan kreatif, pemecahan masalah, dan beberapa 
keterampilan proses serta bersikap ilmiah. Dengan demikian, diharapkan siswa mampu memproses informasi maupun menyelesaikan permasalahan yang berkaitan dengan kehidupan sehari-hari akan lebih kreatif dan bersikap layaknya ilmuwan dalam bekerja.

Pendidik dalam melatih siswa berperilaku layaknya ilmuwan dan keberhasilan dalam mencapai tujuan pembelajaran, diperlukan sebuah model pembelajaran yang merangsang siswa untuk belajar melalui bekerja atau learning by doing didasarkan pada fenomena kehidupan sehari-hari dan permasalahan yang dihadapi. Model pembelajaran yang digunakan harus sesuai dengan karakteristik materi pelajaran dan proses pembelajaran yang berpusat pada siswa learned centered sehingga prestasi belajar siswa dapat meningkat.

Salah satu model pembelajaran yang menunjang pembelajaran learning by doing adalah $C B L$. Model $C B L$ dapat dideskripsikan sebagai bentuk khusus dari pembelajaran berbasis masalah yang bersifat riil dan alamiah. Dalam menghadirkan ide besar yang dapat mencakup keseluruhan proses pembelajaran yang akan dilakukan. Ide besar dapat berasal dari fenomena kehidupan. Dari ide besar yang dihadirkan akan muncul pertanyaan esensial dan tantangan yang harus diselesaikan siswa.

Model $C B L$ dalam penelitian terdapat enam tahap yaitu: Big Idea, Essensial Question, The Challage, Guiding Question, Guiding Activity, dan Solusion. Pada tahap ketiga The challenge (tantangan), dari tantangan diberikan berupa pertanyaan yang mempunyai jawaban spesifik atau solusi yang dapat dihasilkan secara nyata dan tindakan berarti. Pada prosesnya guru mengorientasikan siswa dengan pemberian tantangan kemudian mengurai siswa menganalisis menjadi masalah, mengorganisasi siswa untuk belajar, membimbing penyelidikan individual maupun kelompok, mengembangkan menganalisis dan mengevaluasi proses pemecahan masalah. Metode eksperimen dalam sintaks model $C B L$ dari tahap ke-1 yaitu mengawali dengan memberikan masalah besar (Big idea). Hasil akhir dari proses pembelajaran adalah adanya solusi terhadap tantangan yang dihadirkan dan dapat dilakukan dalam bentuk tindakan, lebih efektif jika diintegrasikan dengan metode eksperimen dan proyek sebab tahapan dalam model ini sangat relevan dengan metode tersebut yang mengorientasikan siswa kepada masalah. Metode eksperimen dan proyek memberikan kesempatan kepada siswa untuk mengembangkan keterampilan proses pada materi listrik dinamis. Adanya keterampilan proses pada siswa maka diharapkan akan terbentuk juga sikap sains siswa.

Materi pelajaran yang dipilih adalah listrik dinamis dengan pertimbangan bahwa materi listrik sangat akrab dengan kehidupan manusia pada umumnya, kehidupan siswa pada khususnya. Selain itu, materi listrik merupakan materi yang bersifat abstrak sehingga sulit bagi siswa. Berdasarkan hasil diskusi dan pengalaman beberapa mahasiswa, kesulitan belajar tentang listrik masih dirasakan hingga tingkat perguruan tinggi. Melalui sebuah tantangan yang dihadirkan untuk diselesaikan siswa maka siswa akan lebih mudah dalam memahami materi tentang listrik yang terkesan sulit dan abstrak.

Berdasarkan uraian di atas, akan dilakukan penelitian dengan penerapan model $C B L$ dengan metode eksperimen dan proyek pada materi listrik dinamis untuk mengetahui prestasi belajar dalam keterampilan berpikir kreatif siswa SMA. Penelitian ini dilakukan untuk memperoleh gambaran tentang prestasi belajar dan keterampilan berpikir kreatif dengan menerapkan pembelajaran berbasis tantangan terhadap penyelesaian masalah, 
serta memeroleh informasi mengenai pembelajaran berbasis tantangan.

Tujuan yang ingin dicapai dalam penelitian ini adalah untuk mengetahui: 1) Pengaruh model $C B L$ dengan menggunakan metode eksperimen dan proyek terhadap prestasi belajar siswa; 2) Pengaruh keingintahuan tinggi dan rendah terhadap prestasi belajar siswa; 3) Pengaruh sikap ilmiah tinggi dan rendah terhadap prestasi belajar siswa; 4) Interaksi antara pengaruh sikap ilmiah dengan dan keingintahuan terhadap prestasi belajar siswa; 5) Interaksi antara pengaruh model $C B L$ dengan metode eksperimen dan proyek dengan sikap ilmiah terhadap prestasi belajar siswa; 6) Interaksi antara pengaruh sikap ilmiah dengan dan keingintahuan terhadap prestasi belajar siswa; 7) Interaksi antara pengaruh model $C B L$ dengan metode eksperimen dan proyek dengan keingintahuan dan sikap ilmiah terhadap prestasi belajar siswa.

\section{METODE PENELITIAN}

Penelitian ini dilakukan di MAN 1 Bandar lampung. Penelitian dilaksanakan pada Tahun Pelajaran 2013/2014 selama 12 bulan yaitu bulan Nopember 2013 sampai bulan Desember 2014. Penelitian ini termasuk dalam jenis penelitian eksperimen semu. Variabel terikat penelitian ini adalah prestasi belajar siswa. Variabel bebas adalah model $C B L$ dengan metode eksperimen dan proyek. Sebagai variabel moderator keingintahuan dan sikap ilmiah siswa.

Populasi pada penelitian ini adalah siswa kelas X MAN 1 Bandar lampung Tahun Pelajaran 2013/2014 terdiri dari 12 kelas. Sampel pada penelitian ini diambil dengan teknik cluster random sampling, kelas yang menjadi sampel adalah kelas X 2 dan X 3.

Penelitian ini menggunakan desain faktorial $2 \times 2 \times 2$. Kelas X 2 diberi perlakuan pembelajaran fisika menggunakan model $C B L$ dengan metode eksperimen dan kelas $\mathrm{X} 3$ diberi perlakukan pembelajaran fisika menggunakan model $C B L$ dengan metode proyek. Kemudian kedua kelas tersebut digolongkan dalam keingintahuan belajar tinggi dan rendah serta sikap ilmiah tinggi dan rendah. Teknik pengumpulan data dalam penelitian ini menggunakan: 1) teknik tes melihat prestasi belajar kognitif siswa pada materi pokok listrik dinamis; 2) teknik non-tes dengan menggunakan metode angket digunakan untuk menilai sikap ilmiah dan keingintahuan siswa, lembar observasi digunakan untuk mengambil data penilaian prestasi belajar afektif dan psikomotorik siswa.

Instrumen pelaksanaan penelitian yang digunakan berupa silabus, rencana pelaksanaan pembelajaran (RPP), lembar kerja siswa (LKS). Uji normalitas yang digunakan adalah uji Kosmogorov Samirnov dan uji homogenitas digunakan adalah uji Levene's. Hipotesis dalam penelitian ini diuji dengan menggunakan uji Anava. Semua uji dilakukan menggunakan software PASW statistic18.

\section{HASIL DAN PEMBAHASAN}

Hasil uji Anava pada prestasi kognitif, afektif dan psikomotorik siswa tersaji pada Tabel 1.

Tabel 1: Hasil pengujian hipotesis ketiga aspek prestasi belajar

\begin{tabular}{|c|c|c|c|}
\hline \multirow{2}{*}{ Hipotesis } & \multicolumn{3}{|c|}{ Taraf Signifikansi } \\
\cline { 2 - 4 } & $\begin{array}{c}\text { Prestasi } \\
\text { Kognitif }\end{array}$ & $\begin{array}{c}\text { Prestasi } \\
\text { Afektif }\end{array}$ & $\begin{array}{c}\text { Prestasi } \\
\text { Psikomotorik }\end{array}$ \\
\hline 1 & 0,033 & 0,743 & 0,682 \\
\hline 2 & 0,010 & 0,037 & 0,575 \\
\hline 3 & 0,014 & 0,710 & 0,909 \\
\hline 4 & 0,237 & 0,195 & 0,535 \\
\hline 5 & 0,540 & 0,126 & 0,375 \\
\hline 6 & 0,868 & 0,076 & 0,110 \\
\hline 7 & 0,894 & 0,567 & 0,068 \\
\hline
\end{tabular}

Berdasarkan hasil uji anava yang dirangkum pada Tabel.1, dapat dijelaskan masing-masing hipotesis sebagai berikut:

1. Pengaruh penerapan $C B L$ dengan menggunakan metode eksperimen dan metode proyek terhadap prestasi belajar siswa. 
Hasil analisis menunjukkan bahwa pembelajaran model $C B L$ dengan metode eksperimen dan proyek terdapat pengaruh terhadap prestasi kognitif siswa pada materi listrik dinamis, namun tidak ada pengaruh terhadap prestasi afektif dan psikomotorik siswa, hal tersebut ditunjukan pada uji hipotesis. Berdasarkan hasil analisis dapat diambil keputusan bahwa kedua kelas yang menggunakan model $C B L$ dengan metode eksperimen dan metode proyek memberikan pengaruh terhadap prestasi kognitif pada materi listrik dinamis.

Proses pembelajaran penggunaan model $C B L$ dengan metode eksperimen dan proyek sama-sama menuntut tanggung jawab setiap siswa dalam mengkonstruksi pemahaman fisika melalui eksperimen kelompok, namun kedua metode tersebut relatif berbeda dalam tahapan-tahapan pembelajarannya. Hal tersebut karena pembelajaran yang menggunakan model $C B L$ dengan metode eksperimen menekankan pada aktivitas eksperimen dalam memecahkan berbagai tantangan dengan menganalisis masalah-masalah, siswa menganalisis tantangan untuk menghasilkan solusi sehingga siswa menjadi semangat untuk menyelesaikan masalah yang dihadapinya. Menurut (Suparno, 2007: 77) metode eksperimen adalah metode mengajar yang mengajak siswa untuk melakukan percobaan sebagai pembuktian, pengecekan akan kebenaran suatu teori.

Pembelajaran menggunakan model $C B L$ dengan metode proyek, lebih menekankan siswa dalam menganalisis tantangan, membuat hipotesis dan membuat konsep-konsep, proses penyelesaian tantangan yaitu melalui serangkaian diskusi dalam kelompok, kemudian siswa membuat hipotesis dan kesimpulan dari hasil kegiatan dalam bentuk laporan, namun dengan metode ini siswa merasa kesulitan dalam merancang konsep penyelesaian yang dihadapi pada materi listrik dinamis jika tidak mendapat bimbingan dari guru. Hasil studi Cheung, (2010) dengan merumuskan tantangan berdasarkan daya tarik pada siswa, siswa bekerja bersama-sama dalam kelompok dalam memikirkan solusi untuk menjawab tantangan. Hasil penelitian ini mampu untuk meningkatkan keterampilan siswa. Hasil penelitian ini menunjukkan bahwa metode pembelajaran tersebut baik digunakan pada proses pembelajaran fisika untuk memecahkan tantangan khususnya pada pokok bahasan listrik dinamis.

Penerapan pembelajaran model $C B L$, siswa diberikan materi listrik dinamis dalam bentuk tantangan, siswa bekerja bersama dan diskusi dalam kelompok dan dibimbing dalam eksperimen untuk menjawab tantangan dalam menganalisis satu persatu permasalahan yang ada, misalnya menganalisis penyebab mengalirnya arus listrik, siswa menganalisis penyebabnya dan menentukan indikatornya. Siswa membandingkan nyala bola lampu yang dicatu dengan tegangan yang berbeda siswa menganalisis kemudian menghadirkan tantangan berupa permasalahan yang mempengaruhi terang redupnya nyala lampu, kemudian dihubungkan dengan tantangan berikutnya faktor-faktor yang mempengaruhi besar/kecilnya hambatan suatu penghantar. Pada akhir pelajaran guru memberikan penjelasan dan kesimpulan dari materi yang telah dipelajari.

Tahap akhir proses pembelajaran guru memberikan penjelasan dan kesimpulan dari materi yang telah dipelajari. Pembelajaran $C B L$ juga dapat melatih ketiga aspek keterampilan berpikir kreatif, yaitu: fluency, flexibility, dan elaboration. Melalui apersepsi siswa akan dirangsang untuk menyebutkan sebanyak mungkin indikator yang ada, yang berkaitan dengan fisika khususnya pada materi listrik dinamis. Flexibility akan terlatih pada saat siswa membandingkan satu masalah dengan masalah lainnya yang masih berkaitan dengan konsep fisika dan elaboration akan terlatih pada saat siswa mencoba 
menjelaskan atau menelaah mengapa sebuah masalah dapat terjadi. Siswa yang dibelajarkan dengan metode eksperimen dituntut untuk mampu melakukan dan menyusun sendiri alat-alat percobaan yang akan digunakan, serta dapat mengulangi percobaan jika hasilnya belum sesuai. Hasil penelitian ini menunjukkan bahwa metode pembelajaran tersebut baik digunakan pada proses pembelajaran fisika untuk memecahkan tantangan khususnya pada pokok bahasan listrik dinamis. (Jatmiko P.S., 2011) dalam penelitian menyimpulkan penerapan pendekatan $C B L$ secara signifikan dapat lebih meningkatkan keterampilan berpikir kreatif siswa dibandingkan dengan penggunaan pembelajaran konvensional.

Berdasarkan penjelasan di atas dapat disimpulkan bahwa penggunaan metode pembelajaran eksperimen lebih baik dari pada metode proyek pada materi listrik dinamis terhadap keterampilan berpikir kreatif atau pada prestasi belajar kognitif. Hal ini sesuai dengan teori bahwa metode merupakan faktor eksternal yang mempengaruhi prestasi belajar siswa.

2. Pengaruh keingintahuan tinggi dan rendah terhadap prestasi belajar siswa.

Hasil analisis menunjukkan bahwa terdapat perbedaan pengaruh antara keingintahuan tinggi dan rendah terhadap prestasi kognitif dan afektif siswa, namun tidak terdapat pengaruh keingintahuan belajar tinggi dan rendah terhadap prestasi psikomotorik siswa.

Keingintahuan merupakan keseluruhan daya peningkat di dalam diri siswa yang menimbulkan keingintahuan terhadap proses belajar mengajar, menjamin kelangsungan dari kegiatan belajar dan memberikan arah pada kegiatan belajar sehingga tujuan yang dikehendaki oleh subyek belajar tercapai (Sardiman, 2006). Adanya keingintahuan belajar tinggi berarti memiliki kebiasaan untuk mempelajari materi fisika di rumah sebelum diajarkan di sekolah, bertanya pada guru tentang kesulitan yang dialami meski di luar jam pelajaran, aktif mengikuti diskusi dengan teman dalam mengerjakan tugas, dan gemar memperkaya pemahaman dengan membaca buku fisika dan mengunjungi perpustakaan.

Rasa keingintahuan siswa dalam proses pembelajaran model $C B L$ merupakan faktor yang berperan penting dalam memahami suatu tantangan, terutama dalam menganalisis berbagai masalah-masalah pada ide besar. Rasa ingin tahu siswa beraneka ragam ketika tantangan-tantangan dihadirkan yang berhubungan dengan materi listrik dinamis. Rasa ingin tahu ketika ide besar dihadirkan, missal PLN dapat mengalirkan listrik hingga jangkauan yang jauh, maka rasa ingin tahu siswa terhadap: penyebab lampu seketika menyala yaitu a) karena terdapat konduktor, proses konduktor dapat mengalirkan arus listrik; b) karena ada bedapotensial, sumber tegangan listrik berasal; c) karena ada arus yang mengalir, dan ingin mengetahui proses mengalirnya arus dalam konduktor. Rasa ingin tahu siswa dalam menganalisis satu persatu masalah yang dihadirkan untuk mendapatkan hasil pengamatannya.

Siswa yang mempunyai keingintahuan belajar tinggi akan memperoleh prestasi belajar yang tinggi, sedangkan siswa dengan keingintahuan rendah memperoleh prestasi belajar yang rendah juga. Berdasarkan uji hipotesis, siswa yang mempunyai keingintahuan belajar tinggi rerata prestasi kognitifnya lebih besar dibandingkan rerata prestasi kognitif yang mempunyai keingintahuan belajar rendah. Sesuai dengan teori bahwa "Anak yang memiliki keingintahuan tinggi akan menanggapi secara positif terhadap pelajaran yang diberikan oleh gurunya" (Suharsimi Arikunto, $2006: 81$ ).

3. Pengaruh sikap ilmiah tinggi dan rendah terhadap prestasi belajar siswa.

Hasil analisis menunjukkan bahwa terdapat perbedaan pengaruh sikap ilmiah 
tinggi dan rendah terhadap prestasi kognitif. Artinya rerata prestasi kognitif ada perbedaan pada kedua kategori, namun tidak terdapat pengaruh sikap ilmiah tinggi dan rendah terhadap prestasi afektif dan psikomotorik siswa pada materi listrik dinamis. Rerata prestasi afektif dan psikomotorik relatif sama pada kedua kategori.

Sikap ilmiah siswa merupakan sikap siswa terhadap objek tertentu tidak hanya sikap terhadap pandangan atau sikap perasaan, tetapi juga sikap yang disertai kecenderungan untuk bertindak sesuai dengan prosedur ilmiah terhadap objek. Komponen sikap ilmiah yang ditinjau dalam penelitian ini meliputi: cermat, disiplin, tanggung jawab, menghargai pendapat orang lain, mampu menyampaikan pendapat dan kritis terhadap permasalahan.

Proses pembelajaran model $C B L$ siswa diberi kesempatan untuk memahami konsep tertentu melalui kegiatan pembelajaran yang dapat mengembangkan keterampilan berpikir siswa, serta sikap ilmiah yang teraplikasi dengan baik, sehingga siswa terlibat aktif dalam proses pembelajaran. Sikap ilmiah merupakan faktor internal, dalam memahami materi fisika dan dalam memahami tantangan yang dihadirkan, sikap ilmiah muncul ketika proses pengamatan materi listrik dinamis. Sikap ilmiah siswa ketika tantangan dihadirkan, dalam penggunaan alat-alat rumah tangga setrika dan hair dryer tiba-tiba rusak, maka sikap ilmiah siswa muncul berupa sifat kritis terhadap tantangan yang menyebabkan siswa bertindak serta menganalisis satu persatu masalah yang dihadirkan yaitu apa yang menjadi penyebab alat rusak, mencaba mengamati melihat komponen di dalamnya, mengamati elemen penyusun, dan bagaimana dengan hambatan listrik dalam rangkaian. Dengan demikian, siswa yang mempunyai sikap ilmiah tinggi akan mudah memahami konsep-konsep yang mereka pelajari.
(Antomi Saregar, 2013) dalam hasil penelitian menyimpulkan siswa yang mempunyai sikap ilmiah tinggi akan mendapatkan prestasi belajar yang tinggi, dibandingkan siswa dengan sikap ilmiah rendah.

Berdasarkan uji hipotesis terdapat perbedaan prestasi kognitif siswa yang mempunyai sikap ilmiah tinggi dan rendah. Hal ini disebabkan siswa yang mempunyai sikap ilmiah tinggi mempunyai kemudahan untuk memahami materi karena siswa aktif bertanya dan teliti terhadap masalahmasalah yang dihadapi dalam pembelajaran dan pada akhirnya akan semakin banyak pula konsep yang dipahami sehingga siswa yang mempunyai sikap ilmiah tinggi akan lebih mudah memahami konsep dibanding siswa yang memiliki sikap ilmiah rendah. Berdasarkan hasil studi Liu, (2005) menunjukkan ada peningkatan yang signifikan terhadap pengetahuan sains siswa dari pre-test ke post-test. Sikap siswa, pengetahuan sains dan motivasi terhadap sains lebih tinggi setelah pembelajaran.

4. Interaksi antara pengaruh penggunaan metode eksperimen dan proyek dengan keingintahuan terhadap prestasi belajar siswa.

Interaksi antara model $C B L$ metode eksperimen dan proyek dengan keingintahuan siswa tidak terdapat pengaruh terhadap prestasi belajar siswa. Artinya rerata prestasi kognitif, afektif, dan psikomotorik relatif sama pada kedua metode yang diterapkan dalam materi listrik dinamis.

Pembelajaran model $C B L$ menggunakan metode eksperimen dalam kegiatan belajar mengajar bertujuan menggali berbagai fakta, informasi, atau data yang diperoleh melalui pengamatan pada proses eksperimen. Pembelajaran model $C B L$ menggunakan metode proyek merupakan metode pembelajaran yang berusaha menumbuhkan motivasi, merancang dari dalam (intrinsik) peserta 
didik (Ratna Wilis Dahar, 1989). Hasil prestasi kognitif, afektif, dan psikomotorik dari penggunaan model $C B L$ dengan metode eksperimen dan proyek relatif sama.

Berdasarkan hasil analisis pembelajaran fisika menggunakan metode eksperimen dan proyek dengan keingintahuan belajar tinggi, maka siswa sama-sama dapat menghasilkan banyak gagasan/jawaban yang relevan terhadap suatu bentuk susunan rangkaian listrik dan dapat memformulasikan jenis rangkaian kombinasi seri dan parallel pada saat proses pembelajaran. Hal tersebut terbukti dari rerata keingintahuan tinggi dan rendah relatif sama, rerata tidak berbeda disebabkan tahapan-tahapan dalam pembelajarannya relative sama dalam penerapan, sedangkan pada hipotesis pertama keingintahuan diperlukan oleh siswa dalam meningkatkan prestasi belajar kognitif, afektif, dan psikomotorik siswa. Belajar dapat diklasifikasikan ke dalam dua dimensi. Dimensi pertama berhubungan dengan cara informasi atau penyajian materi pelajaran kepada siswa, melalui penerimaan atau penemuan. Dimensi kedua menyangkut proses siswa dapat menguraikan informasi itu pada struktur kognitif yang telah ada.

Dapat disimpulkan tidak terdapat interaksi antara model $C B L$ dengan metode eksperimen dan proyek dengan keingintahuan terhadap prestasi belajar kognitif, afektif, dan psikomotorik siswa.

5. Interaksi antara pengaruh penggunaan metode eksperimen dan proyek dengan sikap ilmiah terhadap prestasi belajar siswa.

Hasil analisis menunjukan bahwa interaksi antara model $C B L$ menggunakan metode eksperimen dan proyek dengan keingintahuan siswa tidak terdapat pengaruh terhadap prestasi kognitif, afektif dan psikomotorik siswa. Artinya rerata prestasi kognitif, afektif, dan psikomotorik siswa relatif sama terhadap kedua metode, pada materi listrik dinamis.

Sikap ilmiah merupakan faktor internal yang ada pada diri siswa dalam proses pembelajaran. Faktor internal dapat berpengaruh dalam keberhasilan proses pembelajaran. Dalam proses pembelajaran harus berlangsung secara aktif dan integratif dengan memperhatikan sikap dan menggunakan berbagai metode untuk mencapai suatu tujuan. Tidak adanya interaksi metode pembelajaran dengan sikap ilmiah siswa dalam penelitian ini dapat dijelaskan berdasarkan hipotesis ketiga, pembelajaran dengan model $C B L$ dengan metode eksperimen dan proyek memberikan dampak yang relatif sama terhadap prestasi belajar kognitif, afektif, dan psikomotorik siswa. Tahapan pembelajaran antara metode eksperimen dan proyek berbeda, namun rerata pada metode eksperimen dengan sikap ilmiah tinggi dengan sikap ilmiah rendah persentasenya relatif sama, pada metode proyek rerata siswa yang mempunyai sikap ilmiah tinggi relatif sama dengan siswa yang mempunya sikap ilmiah rendah.

Proses pembelajaran model $C B L$ dengan metode eksperimen dan proyek, siswa yang memiliki sikap ilmiah tinggi dapat melakukan proses pemecahan masalah melalui serangkaian kegiatan eksperimen untuk menemukan solusi dari permasalahan tersebut sehingga siswa dapat mengetahui pengetahuan sendiri. Penyelesaian masalah secara ilmiah ialah penyelesaian masalah secara rasioanal melalui proses deduksi dan induksi (Ratna Wilis Dahar, 1989).

Proses pembelajaran yang baik harus melibatkan siswa dengan situasi-situasi siswa itu sendiri yang melakukan eksperimen. Dengan demikian, dapat disimpulkan bahwa tidak terjadi interaksi antara metode pembelajaran dengan sikap ilmiah belajar siswa. 
6. Interaksi antara pengaruh keingintahuan dengan sikap ilmiah terhadap prestasi belajar siswa.

Hasil analisis menunjukan bahwa interaksi antara keingintahuan belajar dengan sikap ilmiah siswa tidak terdapat pengaruh terhadap prestasi belajar kognitif, afektif, dan psikomotorik siswa. Artinya rerata prestasi kognitif, afektif, dan psikomotorik siswa relatif sama antara keingintahuan terhadap sikap ilmiah siswa, pada materi listrik dinamis.

Penguasaan konsep dalam proses pembelajaran materi listrik dinamis dapat berhasil apabila dalam proses pembelajaran guru dapat mengetahui rasa keingintahuan siswa dalam belajar, maka akan lebih mudah dalam menyampaikan materi, sehingga siswa dapat memahami konsepkonsep dengan mudah. Terdapat kecenderungan siswa dengan keingintahuan belajar dengan sikap ilmiah tinggi menghasilkan rerata hasil belajar yang lebih baik dibandingkan dengan siswa yang mempunyai keingintahuan belajar dengan sikap ilmiah rendah. Tidak adanya interaksi sikap ilmiah terhadap keingintahuan siswa mungkin karena instrumen pengambilan data untuk memperoleh informasi tentang sikap ilmiah siswa hanya diperoleh dari angket saja. Salah satu kelemahan angket sebagai instrumen pengambilan data adalah bersifat subjektif atau hanya berdasar pada pengakuan sepihak saja dari siswa sehingga data sikap ilmiah yang diperoleh kurang akurat.

Berdasarkan analisis keingintahuan dan sikap ilmiah mempunyai karakteristik yang berbeda, namun untuk keduaduanya bisa dimiliki dalam diri siswa. Siswa yang mempunyai keingintahuan tinggi biasanya juga mempunyai sifat ilmiah yang tinggi juga sehingga siswa lebih mudah dalam memahami konsep, membuat gagasan yang relevan dalam mengembangkan, menambah, memperkaya suatu gagasan dalam menjelaskan materi listrik dinamis, misal menjelaskan tingkat kecerahan lampu. Keingintahuan dan sikap terbentuk serta berubah sejalan dengan perkembangan individu, sehingga siswa yang memiliki sikap ilmiah biasanya memiliki kebiasaan untuk teliti, disiplin dan berpikir kritis terhadap fenomena alam yang terjadi menggunakan metode ilmiah.

Pendidikan tidak dapat lepas dari proses pembelajaran di kelas, sedangkan proses pembelajaran di kelas selalu berhubungan dengan pemilihan pendekatan pembelajaran, metode pembelajaran yang tepat serta dibutuhkan keingintahuan dan sikap ilmiah yang baik dari peserta didik dalam merespon proses tersebut. Pemilihan metode dan media pembelajaran yang akan diguanakan harus sesuai dengan karakteristik siswa dan karakteristik materi yang diajarkan, sehingga diharapkan dapat meningkatkan keterampilan berpikir dan prestasi fisika siswa. (Winkel W.S., 1983) sikap sebagai kecenderungan untuk bereaksi secara positif (menerima) atau secara negatif (menolak) terhadap suatu objek berdasarkan suatu penilaian terhadap objek itu sebagai objek yang berharga. Dalam sikap terdapat komponen kognitif, afektif, dan psikomotorik. Berdasarkan uraian di atas, dapat disimpulkan bahwa tidak terjadi interaksi antara keingintahuan belajar tinggi dan rendah dan sikap ilmiah tinggi dan rendah siswa.

7. Interaksi antara pengaruh model $C B L$ menggunakan metode eksperimen dan proyek dengan keingintahuan dan sikap ilmiah terhadap prestasi siswa.

Berdasarkan hasil analisis variansi tiga jalan menunjukan bahwa interaksi antara model $C B L$ menggunakan metode eksperimen dan proyek dengan keingintahuan dan sikap ilmiah siswa tidak terdapat pengaruh terhadap prestasi belajar siswa. Hal ini karena rerata prestasi kognitif, afektif, dan psikomotorik siswa relatif sama pada kedua metode yang diterapkan. 
Pembelajaran dengan menggunakan model $C B L$ dengan metode eksperimen dan proyek dengan keingintahuan dan sikap ilmiah siswa pada materi listrik dinamis, dalam proses pembelajaran menunjukkan rata-rata prestasi belajar siswa terhadap keingintahuan tinggi dan rendah terhadap sikap ilmiah tinggi dan rendah siswa. dari dua kelas eksperimen dan proyek relatif sama pada kedua metode. Keingintahuan dan sikap ilmiah mempunyai peran yang sama dalam proses belajar mengajar. Keingintahuan dan sikap ilmiah yang tinggi akan menghasilkan prestasi belajar yang tinggi pula. Tidak menutup kemungkinan siswa dengan sikap ilmiah rendah yang diberi pembelajaran dengan menggunakan pendekatan $C B L$ dengan metode eksperimen dapat memperoleh prestasi belajar fisika yang tinggi karena siswa tersebut memiliki keingintahuan yang positif dalam proses ilmiahnya. Siswa yang mempunyai keingintahuan rendah, tetapi mempunyai sikap ilmiah tinggi akan memperoleh prestasi belajar yang lebih baik dengan menggunakan metode proyek.

Berdasarkan analisis, tingkat keingintahuan dan sikap ilmiah siswa dalam pembelajaran model $C B L$ dengan metode eksperimen dan proyek memberikan dampak yang relatif sama terhadap prestasi belajar kognitif, afektif dan psikomotorik siswa, sementara jika dilihat dari keingintahuan siswa, terhadap metode pembelajaran adapun yang diterapkan dan pada tingkat keingintahuan tinggi/rendah, siswa yang memiliki keingintahuan tinggi akan memiliki prestasi belajar yang lebih baik dari pada siswa yang memiliki keingintahuan rendah. Jika dilihat dari sikap ilmiah siswa, metode apapun yang diterapkan, dengan sikap ilmiah tinggi/rendah, maka siswa yang memiliki sikap ilmiah tinggi akan memiliki prestasi belajar yang lebih baik dari siswa yang memiliki sikap ilmiah rendah.

Interaksi antara model $C B L$ menggunakan metode eksperimen dan proyek dengan keingintahuan dan sikap ilmiah siswa tidak terdapat pengaruh terhadap prestasi belajar siswa, hal ini tidak relevan dengan penelitian yang dilakukan oleh Baloian dan Nelson (2005) pada penelitian tersebut menunjukkan bahwa diterapkannya strategi $C B L$ sebagai sarana untuk mendorong siswa memperoleh satu fokus yang kuat dalam belajar, kerjasama serta berpikir secara berbeda tentang belajar mandiri.

Meskipun penelitian ini telah direncanakan dengan optimal dan telah melalui proses evaluasi namun tetap tidak luput dari keterbatasan. Beberapa hal yang menjadi keterbatasan dalam melaksanakan penelitian ini antara lain: 1) Penggunaan model $C B L$ dengan metode proyek pada mata pelajaran fisika di MAN 1 Bandar lampung belum pernah dilakukan, sehingga pada saat proses pembelajaran siswa masih bingung ketika melaksanakan kegiatan pemecahan masalah; 2) Pendekatan dan metode pembelajaran yang digunakan dalam penelitian ini selain memiliki kelebihan, tentu juga memiliki kelemahan. Hal ini dapat mempengaruhi hasil penelitian; 2) Penelitian ini hanya melibatkan sebagian faktor dari keseluruhan faktor yang dapat mempengaruhi prestasi belajar fisika siswa, meliputi metode pembelajaran, kemampuan siswa dalam menggunakan alat ukur fisika, dan sikap ilmiah siswa; 3) Banyak faktor yang mempengaruhi keterampilan berpikir kreatif siswa, sedangkan dalam penelitian ini hanya meneliti beberapa faktor yaitu model dan metode pembelajaran sebagai faktor eksternal siswa dan keingintahuan serta sikap ilmiah sebagai faktor internal. Faktor sarana prasarana, input (siswa) dan lingkungan juga berpengaruh terhadap prestasi belajar siswa.

\section{KESIMPULAN}

Berdasarkan data yang telah dikumpulkan dan hasil analisis data yang telah dikemukakan maka dapat 
disimpulkan sebagai berikut: 1) ada pengaruh model $C B L$ dengan metode eksperimen dan proyek terhadap prestasi belajar kognitif sedangkan prestasi afektif dan psikomotorik tidak ada pengaruh; 2) ada pengaruh keingintahuan belajar terhadap prestasi belajar kognitif dan afektif sedangkan prestasi belajar psikomotorik tidak ada; 3) ada pengaruh sikap ilmiah terhadap prestasi belajar kognitif siswa, sedangkan pada afektif dan psikomotorik tidak ada; 4) tidak ada interaksi antara pengaruh model $C B L$ menggunakan metode eksperimen dan metode proyek dengan keingintahuan terhadap prestasi belajar kognitif, afektif, dan psikomotorik siswa; 5) tidak ada interaksi antara pengaruh model $C B L$ menggunakan metode eksperimen dan metode proyek dengan sikap ilmiah terhadap prestasi belajar kognitif, afektif, dan psikomotorik siswa; 6) tidak ada interaksi antara pengaruh keingintahuan belajar dengan sikap ilmiah terhadap prestasi belajar kognitif, afektif, dan psikomotorik siswa; 7) tidak ada interaksi antara pengaruh model $C B L$ menggunakan metode eksperimen dan metode proyek, dengan keingintahuan belajar dan sikap ilmiah terhadap prestasi belajar kognitif, afektif, dan psikomotorik siswa.

\section{SARAN}

Kepada guru: 1) Dalam penggunaan pembelajaran $C B L$ metode eksperimen hendaknya dilakukan dengan persiapan yang matang, sehingga pembelajaran dapat berjalan sesuai dengan rencana, maka dalam pembelajaran perlu: a) Menyiapkan rancangan tantangan pembelajaran yang akan digunakan, berupa pertanyaan tantangan materi yang akan diajarkan beserta alat evaluasinya; b) Kuasai materi yang akan disampaikan; c) Bagi kelompok seheterogen mungkin sehingga terjadi interaksi siswa diantara kelompoknya; d) Siswa hendaknya di beri penjelasan terlebih dahulu dalam menggunakan alat-alat percobaan, karena kebanyakan siswa mengalami kesulitan dalam merangkai alat. 2) Mempertimbangkan ketersediaan alat dan bahan praktikum yang ada di laboratorium sekolah sejak awal agar waktu dan pelaksanaan praktikum dapat berjalan secara lancar. Kepada peneliti lain: 1) Hasil penelitian ini dapat dijadikan acuan untuk penelitian yang sejenis dengan materi pelajaran yang berbeda; 2) Penelitian ini dapat dikembangkan dengan menambah variabel lainnya seperti kemampuan awal, aktivitas belajar, kreativitas belajar, gaya belajar, dan lain-lain.

\section{DAFTAR PUSTAKA}

Baloian dan Nelson. (2001). Implementing the Challenge Based Learning in Classroom Scenarios. Parts of this work have been supported by the European IST project no.-32327.

Cheung, Ronald S. (2010) Challenge Based Learning in Cybersecurity Education. International Journal of Social Sciences. Department of Computer Science, University of Massachusetts, Boston, MA, USA. (cheungr@cs.umb.edu)

Jatmiko, P.S. (2011). Penerapan challenge based learning untuk meningkatkan penguasaan konsep listrik dinamis dan keterampilan berpikir kreatif siswa sma. Bandung: Sekolah Pascasarjana UPI.

Liu. (2005). Motivating Students Through Problem-based Learning. University of Texas - Austin. Jurnal of interactif Learning Research (2006) 17 (3), 225-242

Ratna Wilis Dahar. (1989) Teori-Teori Belajar. Jakarta: Erlangga.

Sardiman. (2006). Interaksi dan Motivasi Belajar Mengajar. Jakarta:Rajawali Pers.

Suharsimi Arikunto. (2006). Prosedur Penelitian Suatu Pendekatan Praktik. Jakarta: Rineka Cipta. 
Suparno, Paul. (2007). Metodologi

Pembelajaran Fisika Konstruktivis

dan Menyenangkan. Yogyakarta: Universitas Sanata Dharma.

Winkel, W.S. (1983). Psikologi Pendidikan dan Evaluasi Belajar. Jakarta: Gramedia. 